\title{
BMJ Global Health Building back from the ground up: the vital role of communities
}

To cite: Doherty T, Kroon M, Reynolds L, et al. Building back from the ground up: the vital role of communities. BMJ Global Health 2020;5:e003928. doi:10.1136/ bmjgh-2020-003928

Received 9 September 2020 Accepted 13 September 2020

Check for updates

(c) Author(s) (or their employer(s)) 2020. Re-use permitted under CC BY-NC. No commercial re-use. See rights and permissions. Published by BMJ

${ }^{1}$ Health Systems Research Unit, South African Medical Research Council, Tygerberg, South Africa ${ }^{2}$ Paediatrics and Child Health, University of Cape Town Faculty of Health Sciences, Observatory, South Africa

${ }^{3}$ School of Public Health, University of the Western Cape, Cape Town, South Africa

${ }^{4}$ Neonatology, University of Cape Town Faculty of Health Sciences and Mowbray Maternity Hospital, Observatory, South Africa

${ }^{5}$ People's Health Movement Cape Town, South Africa ${ }^{6}$ Obstetrics and Gynaecology, Faculty of Health Sciences, University of Cape Town, Cape Town, South Africa

${ }^{7}$ Children's Institute, University of Cape Town, Cape Town, South Africa

${ }^{8} \mathrm{Health}$ Economics Unit, School of Public Health and Family Medicine, University of Cape Town, Cape Town, South Africa

Correspondence to

Professor Tanya Doherty;

tanya.doherty@mrc.ac.za

\author{
Tanya Doherty (10 , ${ }^{1,2,3}$ Max Kroon, ${ }^{4}$ Louis Reynolds, ${ }^{2,5}$ Sue Fawcus, ${ }^{6}$ Lori Lake, ${ }^{7}$ \\ Geetesh Solanki ${ }^{1,8}$
}

\section{INTRODUCTION}

Globally the COVID-19 pandemic has destabilised health systems and communities. Governments in low- and middle-income countries (LMICs) followed the approaches adopted by the Global North and advocated by international bodies such as the WHO, and instituted varying degrees of nationwide stay at home orders (lockdowns) from strict restrictions (such as in South Africa, India and Zimbabwe) to weakly enforced lockdown as in Brazil. ${ }^{1}$ Many have questioned the appropriateness of these measures in LMIC contexts ${ }^{2}$ where key preventive behaviours such as social distancing and frequent hand washing are impossible to implement in densely populated informal housing settlements. People rely on crowded public transport to get to work, households are cramped and lack easy access to water and sanitation; loss of income leads to food insecurity and hunger as well as high levels of stress and violence. In such conditions viral spread is impossible to control and economic devastation is inevitable. In this commentary we examine (1) some of the unintended impacts of this approach for LMICs and (2) the steps that need to be taken in the short-term and longer-term to mitigate these impacts and the vital role of civil society and communities in this recovery process.

\section{COVID-19 UNINTENDED IMPACTS}

The response from LMIC governments to contain the COVID-19 pandemic aimed primarily to limit virus spread. The unintended consequences of the instituted measures are wide reaching. UNICEF reports from the early months of the COVID-19 pandemic suggest a $30 \%$ reduction in the coverage of essential nutrition services in LMICs and declines of $75 \%$ to $100 \%$ under lockdown contexts. ${ }^{3}$ A preliminary assessment by the UN Food and Agricultural Organization
Summary box

The medicalised response to COVID-19 in low- and middle-income countries has had unintended and far-reaching consequences.

- Communities, non-governmental organisations and civil society organised themselves from the 'groundup' to alleviate the economic, social and health impacts of COVID-19.

- Urgent intersectoral mitigation strategies required for COVID-19 recovery will not be fulfilled through state services alone.

- Investing in community cadres and organisations has the potential to build social solidarity, mitigate the impact of COVID-19 and strengthen intersectoral collaboration and safety nets for future crises.

suggests the pandemic may add between 83 and 132 million people globally to the total number of undernourished in 2020 as a result of loss of income and livelihoods. ${ }^{4}$

In terms of health service access, a WHO survey reported that $55 \%$ of essential health services were at least partially disrupted in the African region in response to the pandemic. Family planning services were disrupted in $68 \%$ of countries, $53 \%$ of countries reported partial disruptions in antenatal care services and $32 \%$ in facility-based birth services. ${ }^{5}$ Despite WHO and country guidance to the contrary, mother-newborn separation has occurred in many LMICs. Research from Nepal has described a $3.5 \%$ decline in breast feeding within 1 hour of birth during lockdown, from an already low rate of $46 \%$. Disruption or suspension of outreach immunisation services was reported by $86 \%$ of countries in the African region and disruption of immunisation services at health facilities for $44 \%$ of countries. ${ }^{7}$

Lockdowns exacerbated the silent pandemic of gender-based and intimate partner violence in countries with already high levels. Research undertaken during the lockdown in Bangladesh found significantly increased 
Table 1 Illustrative examples of areas indirectly affected by COVID-19 requiring mitigation measures

\begin{tabular}{|c|c|c|}
\hline Issue & COVID-19 impact & Mitigation measures \\
\hline \multicolumn{3}{|c|}{ Short- term measures } \\
\hline Birth registration & $\begin{array}{l}\text { Birth registration stopped during country } \\
\text { lockdowns. Sustainable Development } \\
\text { Goal target } 16.9 \text { aims to achieve universal } \\
\text { registration of all births by } 2030 \text {. }\end{array}$ & $\begin{array}{l}\text { Temporary processing of birth certificates at health } \\
\text { facilities to catch up infants not registered at birth. } \\
\text { Visits by } \mathrm{CHW} \text { s to all households with children } \\
\text { under } 1 \text { year to check birth registration status. }\end{array}$ \\
\hline Breast feeding & $\begin{array}{l}\text { Potential for declines due to mother-infant } \\
\text { separation and health worker fears of } \\
\text { COVID-19 transmission. }\end{array}$ & $\begin{array}{l}\text { Rapidly disseminate strong messages through } \\
\text { community-based organisations and CHWs about } \\
\text { the importance of breast feeding in the context } \\
\text { of COVID-19, and the harmful consequences of } \\
\text { separating mothers and newborns. }\end{array}$ \\
\hline Immunisation & $\begin{array}{l}\text { Declines in routine immunisation due to } \\
\text { health service disruptions, reallocation of } \\
\text { staff to COVID- } 19 \text { and fears of mothers to } \\
\text { attend health facilities. }\end{array}$ & $\begin{array}{l}\text { Visits by } \mathrm{CHWs} \text { to all households with children } \\
\text { under } 5 \text { years of age to check immunisation } \\
\text { status. } \\
\text { Catch up immunisation campaigns in schools and } \\
\text { Early Child Development centres. }\end{array}$ \\
\hline Chronic medication & $\begin{array}{l}\text { Disruptions to chronic medication } \\
\text { distribution leading to gaps in adherence. }\end{array}$ & $\begin{array}{l}\text { Establish community distribution points } \\
\mathrm{CHWs} \text { supporting medication distribution to } \\
\text { households with elderly or ill. }\end{array}$ \\
\hline
\end{tabular}

\section{Long-term measures}

\begin{tabular}{lll}
$\begin{array}{l}\text { Weak community platform } \\
\text { with too few CHWs to } \\
\begin{array}{l}\text { augment public sector } \\
\text { response to crises }\end{array}\end{array}$ & $\begin{array}{l}\text { CHWs re-assigned to COVID-19 unable to } \\
\text { perform their usual household visits and } \\
\text { functions. }\end{array}$ & $\begin{array}{l}\text { Strengthen community delivery platforms with } \\
\text { increased numbers of CHWs. } \\
\text { High coverage of households to undertake } \\
\text { detailed assessments of COVID-19 recovery } \\
\text { needs. }\end{array}$ \\
$\begin{array}{ll}\text { Lack of forums for } \\
\text { communities/civil society in } \\
\text { decision-making }\end{array}$ & $\begin{array}{l}\text { Civil society actions to support COVID-19 } \\
\text { were implemented in parallel to government } \\
\text { actions with little/no co-ordination } \\
\text { or community consultation on the } \\
\text { appropriateness of government solutions. }\end{array}$ & $\begin{array}{l}\text { Policy mandated forums for community } \\
\text { consultation and accountability mechanisms to } \\
\text { ensure feedback and progress tracking. }\end{array}$ \\
$\begin{array}{ll}\text { Prioritisation of domestic } \\
\text { spending }\end{array}$ & $\begin{array}{l}\text { COVID-19 stimulus packages risk deepening } \\
\text { inequity by prioritising large companies } \\
\text { and leaving behind small business and } \\
\text { community enterprises. }\end{array}$ & $\begin{array}{l}\text { Embark on a transparent, participatory } \\
\text { prioritisation process to inform the allocation } \\
\text { of COVID-19 stimulus funding with a focus on } \\
\text { growing 'township' economies. }\end{array}$ \\
\hline
\end{tabular}

CHWs, community health workers.

levels of emotional, physical and sexual violence among women living with their husbands. ${ }^{8}$ In South Africa, data collected from the government gender-based violence and femicide command centre revealed more than 120 000 victims in the first 3 weeks of lockdown. ${ }^{9}$

As a result of these unintended impacts, there is a high probability that COVID-19 will deliver us into the next set of crises in the form of increasing inequality, poverty and food insecurity, outbreaks of vaccine preventable diseases, unintended pregnancies and rising child malnutrition which will be felt for generations to come.

\section{MITIGATION MEASURES AND EQUITY-FOCUSSED RECOVERY}

While LMIC governments have focussed almost exclusively on reducing COVID-19 case numbers, many communities organised themselves with 'ground-up' mitigation measures to address the worsening unintended effects. Examples have emerged from many LMICs of neighbourhood initiatives to support vulnerable families.
In India, the health focussed non-governmental organisation (NGO) Swasti brought together a group of NGOs to found the COVID-19 Action Collaborative. Its 150 member organisations are now coordinating efforts and sharing knowledge to provide integrated health, nutrition, social protection, livelihood and financing support to over 2 million vulnerable people across 15 states. $^{10}$ Women's empowerment groups in Kerala helped to map where older people live to ensure they had access to medicine and food while social distancing. ${ }^{11}$ In South Africa, a movement of self-organising, neighbourhoodlevel community action networks (CANs) has contributed significantly to the community-based response to COVID19. Without any financial support from the government these CANs have initiated community support activities such as establishing community kitchens, developing communication materials, distributing clothing and skills upliftment training. ${ }^{12}$ Concerted civil mobilisation also led to a court case ${ }^{13}$ brought by civil society organisations 
and school governing bodies to have the national school nutrition programme which provides a daily meal to roughly nine million children, reinstated 4 months after school closures.

The intense lockdown periods and burden of COVID19-related illness have revealed the inadequacies of strained, under-resourced public health facilities, and in some instances inept LMIC governments' responses to crises; and the critical role of resilient, mobilised community structures. The urgent intersectoral mitigation strategies required for COVID-19 recovery will not be fulfilled through state services alone. The efforts already being led by NGOs and civil society need to be supported and harnessed, both to develop context-specific solutions and to implement them.

Several areas will require short-term and long-term mitigation measures implemented through strong primary healthcare systems and community participation. Some specific illustrative examples are given in table 1 . An important community cadre that has the potential to play a critical role in mitigation strategies in LMICs are community health workers (CHWs). CHWs have been at the forefront of efforts to screen and trace individuals as part of the COVID-19 response in many LMICs including South Africa, ${ }^{14}$ India ${ }^{15}$ and Brazil. ${ }^{16}$ However, this additional work has meant neglect of their usual functions of providing health promotion, prevention and care to vulnerable families. Long-term COVID-19 mitigation strategies should prioritise increasing the number of CHWs to ensure an optimal ratio of workers to households to cope with the more intensive COVID-19 recovery period. Through home visits CHWs can assess and identify household needs such as catch up immunisation, family planning, antenatal care, growth monitoring, birth registration, HIV, tuberculosis and chronic disease management and mental health.

Increasing the numbers of female CHWs serves not only to improve coverage of care for households and thus a return on investment due to a healthier population, but there are other important societal benefits. Modelling based on the South African situation estimated that increasing the number of CHWs to 96000 (from 60 000) and paying the minimum wage would cumulatively, over 3 years, contribute an additional R13.6 billion (South African rand) to the economy (equivalent to $0.3 \%$ of GDP (gross domestic product)) given that the employed women would spend this salary primarily on the health, education and nutrition of their children thus also benefitting their local community economies. ${ }^{17}$

Appropriately funded community cadres and organisations have the potential to build social solidarity that would enable a more rapid intersectoral response for future crises. The recovery process and accompanying investments (domestic or multilateral) are an opportunity to embark on open and transparent prioritisation processes to determine how best to use resources with a pro-equity focus. Given the enormous constraints facing LMIC governments in the COVID-19 aftermath, it is only through the active participation of communities and civil society in designing and implementing solutions, that lasting sustainable societal improvements will be realised.

\section{CONCLUSION}

The challenges highlighted by the COVID-19 epidemic in LMICs are in many respects an acute manifestation of long-standing chronic problems and the recovery phase should address them. The resource constraints faced by Governments in LMICs (sometimes compounded by inappropriate decision-making and undermined by corrupt disbursement of COVID-19 funding) and the generally weak public healthcare systems of these countries means that they cannot be solely relied on to address such crises. The COVID-19 experience has further demonstrated the contributions communities and civil society can make and the critical need to incorporate them into efforts to mitigate the health, social and economic effects of COVID-19. This is the only way to move towards sustainable positive change that better builds resilience for the inevitable future crises.

Contributors All authors were involved in the conceptualisation and writing of the commentary.

Funding Staff time for TD and GS was supported by the South African Medical Research Council.

Competing interests None declared.

Patient consent for publication Not required.

Provenance and peer review Not commissioned; internally peer reviewed.

Data availability statement There are no data in this work.

Open access This is an open access article distributed in accordance with the Creative Commons Attribution Non Commercial (CC BY-NC 4.0) license, which permits others to distribute, remix, adapt, build upon this work non-commercially, and license their derivative works on different terms, provided the original work is properly cited, appropriate credit is given, any changes made indicated, and the use is non-commercial. See: http://creativecommons.org/licenses/by-nc/4.0/.

\section{ORCID iD}

Tanya Doherty http://orcid.org/0000-0003-1592-0080

\section{REFERENCES}

1 The Lancet. COVID-19 in Brazil: "So what?". The Lancet 2020;395:1461.

2 Kelley M, Ferrand RA, Muraya K, et al. An appeal for practical social justice in the COVID-19 global response in low-income and middleincome countries. Lancet Glob Health 2020;8:e888-9.

3 UNICEF. Situation tracking for COVID-19 socioeconomic impacts. New York UNICEF; 2020. https://data.unicef.org/resources/rapidsituation-tracking-covid-19-socioeconomic-impacts-data-viz/

4 Food and Agricultural Organization of the United Nations. The state of food security and nutrition in the world. Rome: FAO, 2020. http:// www.fao.org/3/ca9692en/CA9692EN.pdf

5 World Health Organization. Pulse survey on continuity of essential health services during the COVID-19 pandemic. Geneva: WHO, 2020. https://www.who.int/publications/i/item/WHO-2019-nCoVEHS_continuity-survey-2020.1

6 Kc A, Gurung R, Kinney MV, et al. Effect of the COVID-19 pandemic response on intrapartum care, stillbirth, and neonatal mortality outcomes in Nepal: a prospective observational study. Lancet Glob Health 2020. doi:10.1016/S2214-109X(20)30345-4. [Epub ahead of print: 10 Aug 2020].

7 World Health Organization. Global immunization news June 2020. Geneva WHO; 2020. https://www.who.int/immunization/GIN_June_ 2020.pdf?ua $=1$ 
8 Hamadani JD, Hasan MI, Baldi AJ, et al. Immediate impact of stayat-home orders to control COVID-19 transmission on socioeconomic conditions, food insecurity, mental health, and intimate partner violence in Bangladeshi women and their families: an interrupted time series. Lancet Glob Health 2020. doi:10.1016/S2214109X(20)30366-1. [Epub ahead of print: 25 Aug 2020].

9 Farber T. Shocking STATs on gender-based violence during lockdown revealed Sowetan Live; 2020. https://www.sowetanlive.co. za/news/south-africa/2020-09-01-shocking-stats-on-gender-basedviolence-during-lockdown-revealed/

10 Venkatachalam P, Yeh D, Memon N. Philanthropy's distinct role in India's COVID-19 response.Devex; 2020. https://www.devex.com/ news/opinion-philanthropy-s-distinct-role-in-india-s-covid-19response-97702

11 Balsari S, Sange M, Udwadia Z COVID-19 care in India: the course to self-reliance. Lancet Glob Health 2020. doi:10.1016/S2214109X(20)30384-3. [Epub ahead of print: 24 Aug 2020].

12 van Ryneveld M, Whyle E, Brady L. What is COVID-19 teaching us about community health systems? A reflection from a rapid Community-Led mutual aid response in Cape town, South Africa. Int $J$ Health Policy Manag 2020. doi:10.34172/ijhpm.2020.167. [Epub ahead of print: 01 Sep 2020].
13 High Court of South Africa. Judgement in the matter between equal education, the school governing body of Vhulaudzi secondary school, the school governing body of Mashao high school and the Minister of basic education. high Court of South Africa. Case number: 22588/2020 Pretoria High Court of South Africa; 2020 https://equaleducation.org.za/wp-content/uploads/2020/07/ Judgment-Equal-Education-and-others-v-Minister-of-BasicEducation-and-others-22588-2020.pdf

14 David N, Mash R. Community-Based screening and testing for coronavirus in Cape town, South Africa: short report. Afr J Prim Health Care Fam Med 2020;12:e1-3.

15 Jha N. India's first line of defense against the coronavirus is an army of 900,000 women without masks or hand sanitizer Buzfeed News; 2020. https://www.buzzfeednews.com/article/nishitajha/indiacoronavirus-cases-ashas

16 Lotta G, Wenham C, Nunes J, et al. Community health workers reveal COVID-19 disaster in Brazil. Lancet 2020;396:365-6.

17 Daviaud E, Besada D, Budlender D, et al. Saving lives, saving costs: investment case for community health workers in South Africa. Cape Town: South African Medical Research Council, 2018. https://www. samrc.ac.za/sites/default/files/files/2017-10-30/SavingLivesSavin gCosts.pdf 